\title{
Teachers' Attitudes Towards the Use of Blended Learning in General English Classroom
}

\author{
Vilma Bijeikienė, Svetlana Rašinskienė, Lina Zutkienė
}

crossref http://dx.doi.org/10.5755/j01.sal.0.18.420

\begin{abstract}
The paper deals with the application of ICT and the use of blended teaching and learning within the curriculum of general English at the levels A1-B2 in tertiary education. The research presented in the paper focuses on analyzing the language teachers' experience in computer assisted language teaching as well as their practices and attitudes towards the blended learning courses created at the Centre of Foreign Languages at Vytautas Magnus University (VMU). Given the fact that the contemporary society is especially sensitive with regard to the development and the application of innovative technologies and given the fact that current and future university students are increasingly 'digital natives', the task of language teachers to make the best use of ICT in teaching languages becomes their most acute need and their biggest challenge. Therefore, the authors of the present paper take it as their aim to ease the above indicated task of the teachers by scrutinizing and casting light on their relevant doubts, needs and endeavours. The research was carried out at the Centre of Foreign Languages (VMU) with 24 teachers of English taking the role of the respondents. The research is based mainly on qualitative methodology including the methods of an informal interview and a questionnaire.
\end{abstract}

Key words: teaching English as foreign language, ICT, CALL, distance learning, blended learning, tertiary education.

\section{Introduction}

Nowadays when various types of e-communication are becoming more widely spread and when letter writing is understood as e-mailing as well as talking to one's friends or relatives as e-chatting, there necessarily arises a need to continuously develop and expand e-teaching/ learning materials and courses. If at present we cannot imagine our lives without e-banking and e-mailing, the future generations will not be able to imagine theirs without distance learning or blended learning. To meet the contemporary needs, in 2009 the Centre of Foreign Languages (VMU) created 4 blended learning courses of general English for tertiary education at the levels A1-B2 according to The Common European Framework of Reference for Languages (2001; Morrow, 2004).

While analysing the possible threats and dangers arising along with the introduction of e-teaching/ learning, Rutkauskiené et.al. (2003, 2007) observe that users might feel anxiety and have fear of losing control of the system, in which case they could lose face by showing themselves as ignorant in ICT. The introduction of digital innovations might be especially face-threatening and challenging to the teachers provided that the current and future university students are increasingly 'digital natives', i.e. born into to the world with ICT widely-spread (cf. Sharma and Barrett, 2007). By contrast, most of the teachers can be regarded as "digital immigrants" (as pointed out by Gary Anderson in his plenary speech at a conference in Kaunas, May 21-22, 2010) who need to adapt themselves to the rapidly changing digital world. Therefore, it is not only the quest of what ICT to blend in and how much of it would allow for the best results, but also their personal wish to keep pace well with the technology that burden language teachers nowadays.
The research problem. With the above assumptions in mind, the present study sees the challenge of effective and optimal integration of ICT into the English language teaching process as a research problem.

The research aims. As a result, the present study firstly aims at analyzing the English language teachers' attitudes to the application of ICT and blended learning in general. It further aims to scrutinize the teachers' attitudes towards the 4 blended learning courses of General English, which were created at the Centre of Foreign Languages (VMU), after one year of their introduction into the curriculum. The main objective of the study is to raise the quality of teaching English through the increased efficiency in the application of ICT which highly depends on the language teachers' ICTawareness and appreciation.

\section{Theoretical Background}

Scholars (e.g. Chapelle and Jamieson, 2008, Sharma and Barrett, 2007) dealing with contemporary methodologies of teaching foreign languages accentuate the fact that the stateof-the-art language learning and teaching technologies closely reflect the current needs, habits and tendencies of the digitalized society. On the one hand, the application of ICT to learning processes creates the learning environment which is similar to the everyday activities of the contemporary learners, as, for instance, using computers for work or entertainment. On the other hand, the application of ICT extends the learners' scope of interaction from the learner-teacher and learnerlearner interaction to the computer-based interactive activities and extends the ways of communication from the face-toface interaction to the communication via electronic means. The continuous alteration and adaptation of the approaches 
towards foreign language pedagogy to the learners' needs is accurately described by Brown as "the changing winds and the shifting sands of language teaching over years" (2001, p.18). Shifting the methods and techniques applied by foreign language teachers is strongly interrelated with their general "philosophy of education" (Brown, 2000, p.7). According to Chapelle and Jamieson (2008), nowadays the traditional components of English language pedagogy, or it can be assumed the foreign language pedagogy in general, can be successfully enriched with the computer component as a helpful and valuable tool (see Figure 1 below):

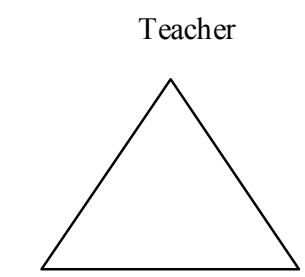

Learner

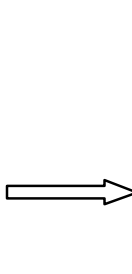

English
Teacher

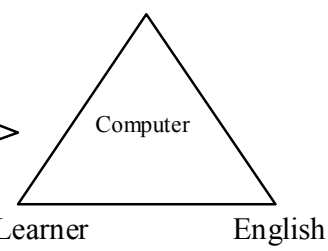

Figure 1. Changing Components in English Language Pedagogy (based on Chapelle and Jamieson (2008, p.2)).

As demonstrated by rich research into this area, the development and application of various types of ICT to learning and teaching foreign languages is not quite a novelty (e.g. Davies, 2000, Malpica et al, 2006, 2008; Kenning, 2008, Shelly, 2000). Chapelle and Jamieson (2008) present vast possibilities for teaching languages with digital technologies in their discussion of CALL, i.e. computerassisted language learning, and the related concepts of WELL and MALL, namely web-enhanced language learning and mobile-assisted language learning, respectively. Blake (2008) brings a fresh angle on the concept of distance learning which he defines as "multimedia programs delivered by CD or DVD disks, Internet materials and activities", teleconferencing as well as asynchronously and synchronously delivered activities in such course management systems as Blackboard, WebCT and Moodle.

The concept of blended learning, which is the primary focus of the present study, has been used and interpreted in a variety of ways within the field of foreign language teaching and beyond; one of the most comprehensive discussions of this concept is presented by Sharma and Barrett (2007). Starting with an overview of the existing definitions of blended learning and building upon such methodological aspects as a combination of online and in-person learning, a mixture of face-to-face and distance learning as well as the incorporation of various ICT technologies and e-learning platforms, Sharma and Barrett generalize their understanding of blended learning as the learning processes where learners meet with a teacher for a face-to-face instruction but in which the course includes "a parallel self-study component such as a CD-ROM or access to web-based materials" (Sharma and Barrett, 2007, p.7). For Sharma and Barrett, the term blended learning is applicable to a variety of teaching and learning situations and pertinent to a broad range of combinations with regard to face-to-face and computer- mediated teaching and learning. In that sense, the concept of blended learning is seen to be broader and more inclusive than distance learning and CALL, which makes blended learning function as a superordinate of the other two terms.

Following the conception set by Sharma and Barrett (2007), the present study defines blended learning as the teaching and learning process where face-to-face instruction is enhanced through the resources and activities designed and accessible in a computerized language learning laboratory and in the virtual Moodle environment. The computerized language learning laboratory used at the Centre of Foreign Languages (VMU) is equipped with SANAKO Lab 300 software for classwork management and ICT for interactive self-study. The courses contained in the virtual Moodle environment include a broad scope of teaching and learning materials such as theory presentations, video lectures, video episodes for discussions, audio records for listening comprehension and interactive tasks. The courses are also equipped with various means of communication, such as discussion forums and chats.

\section{Methodology}

The application of ICT to teaching foreign languages as a state-of-the-art methodological solution has been widely accompanied by research into the attitudes and the needs of the learners (cf. Bijeikienè, Linkevičiūtè and Pundziuvienè, 2009; Daubariené, Rinkevičienè and Zdanytè, 2009; Mačianskienè and Daukšienė, 2008; Makkonen, 2008). In 2009, four blended learning courses were introduced to teaching general English of A1-B2 levels (CEF, 2001) at the Centre of Foreign Languages (VMU). The courses include $20 \%$ or more of instructions in the distance way offered to the students in the virtual Moodle environment and several classes delivered in the computerized Sanako 300 Lab; Moodle was chosen as the virtual environment used for all distance learning and teaching courses at VMU. This new blended learning approach engendered the need to analyse the attitudes of the participants engaged into its application. While most of the similar studies attend to the learners' needs, the present study focuses on the attitudes and the experience of the teachers with 24 English language teachers of the centre taking the role of the respondents.

The study is based on the methodology of a small scale mainly qualitative analysis including the methods of a survey conducted using informal interviews and questionnaires. The research questions formulated for the investigation are as follows:

- What is the respondents' general experience in the use of blended teaching?

- What inadequacies and benefits of blended learning were revealed through the piloting delivery of the general English courses in a blended form?

The investigation was carried out in three stages. The first stage was completed before the actual delivery of the 
blended learning courses. The purpose of the first stage was to collect data about the teachers' general experience in the use of ICT in teaching processes focusing on their work in Sanako $300 \mathrm{Lab}$. At this stage data was obtained using a short questionnaire and the results are delivered in Tables 1 and 2 . The second and the third stages were completed after the delivery of the courses. Another questionnaire was prepared for the second stage in order to investigate the teachers' attitudes towards different aspects of the materials and the activities in the Moodle environment; the data are presented in Figures 2 and 3. Given the relatively small number of the respondents (teachers of English at the Centre of Foreign Languages at VMU), the data in the Tables and Figures are presented in absolute numbers. At the third stage the method of a loosely structured informal interview was applied for a more in-depth discussion of the teachers' experience and opinion with regard to the given courses.

\section{Results and Discussion}

\section{General Experience in Blended Teaching}

The results of the study regarding the first research question, namely the English language teachers' general experience in the use of ICT and blended teaching, are presented in Tables 1 and 2 below. These results were obtained using the method of a questionnaire.

Table 1. Attitude to the Application of ICT (part I).

\begin{tabular}{|l|l|l|l|}
\hline $\begin{array}{l}\text { 1. Do you use ICT in classes } \\
\text { of general English? }\end{array}$ & $\begin{array}{l}\text { 2. Do you prepare interactive } \\
\text { exercises and tests? }\end{array}$ \\
\hline Yes, very often & $\mathbf{1 7}$ & $\begin{array}{l}\text { Yes, I am quite } \\
\text { experienced }\end{array}$ & $\mathbf{2}$ \\
\hline $\begin{array}{l}\text { Yes, sometimes, but I } \\
\text { need more experience }\end{array}$ & $\mathbf{2}$ & $\begin{array}{l}\text { Yes, but I have little } \\
\text { experience }\end{array}$ & $\mathbf{1 4}$ \\
\hline $\begin{array}{l}\text { No, I have no } \\
\text { competence }\end{array}$ & $\mathbf{1}$ & $\begin{array}{l}\text { No, but I would like to } \\
\text { learn }\end{array}$ & $\mathbf{5}$ \\
\hline No, it is not effective & $\mathbf{0}$ & $\begin{array}{l}\text { No, this method is not } \\
\text { effective }\end{array}$ & $\mathbf{0}$ \\
\hline No answer & $\mathbf{4}$ & No answer & $\mathbf{3}$ \\
\hline Total & $\mathbf{2 4}$ & Total & $\mathbf{2 4}$ \\
\hline
\end{tabular}

Table 2. Attitude to the Application of ICT (part II).

\begin{tabular}{|l|c|l|c|}
\hline \multicolumn{3}{|l|}{$\begin{array}{l}\text { 3. Do you find the multimedia } \\
\text { language teaching/learning } \\
\text { laboratory and Sanako soft- } \\
\text { ware effective? }\end{array}$} & $\begin{array}{l}\text { 4. Would you participate in } \\
\text { seminars on the use of ICT } \\
\text { in language teaching? }\end{array}$ \\
\hline Very effective & $\mathbf{7}$ & Yes, of course & $\mathbf{1 7}$ \\
\hline $\begin{array}{l}\text { It would be more } \\
\text { effective if I was more } \\
\text { experienced in using it }\end{array}$ & $\mathbf{1 2}$ & $\begin{array}{l}\text { Yes, but it would not } \\
\text { be my priority }\end{array}$ & $\mathbf{4}$ \\
\hline $\begin{array}{l}\text { I do not use } \\
\text { lab software }\end{array}$ & $\mathbf{0}$ & $\begin{array}{l}\text { No, I would not } \\
\text { benefit }\end{array}$ & $\mathbf{0}$ \\
\hline $\begin{array}{l}\text { No, traditional forms } \\
\text { are more effective }\end{array}$ & $\mathbf{1}$ & $\begin{array}{l}\text { No, I will not use } \\
\text { ICT in teaching }\end{array}$ & $\mathbf{0}$ \\
\hline No answer & $\mathbf{4}$ & No answer & $\mathbf{3}$ \\
\hline Total & $\mathbf{2 4}$ & Total & $\mathbf{2 4}$ \\
\hline
\end{tabular}

Given that the questions were formulated in such a way as to closely reflect the current situation of technological equipment at the teachers' workplace, their answers can be expected to closely reflect the teachers' current practices, attitudes and needs with regard to the application of ICT. The majority of the teachers indicate that the application of ICT is a common practice in their teaching routine, with only one clearly negative answer related to the lack of competence. Along the same lines, most of the teachers express their appreciation of the work in the multimedia language teaching/ learning laboratory equipped with Sanako software, with one answer giving preference to traditional methods. Nevertheless, the majority of the teachers appear to be lacking skills for a more active and creative approach to the use of ICT. On the one hand, most of them highlight their inadequate experience in the preparation of interactive teaching and testing materials. On the other hand, most of them reveal that their higher competence in ICT would allow for a more effective teaching in the multimedia lab. Finally, the teachers express their determination to use ICT in the future by indicating their willingness to increase their competence in specialized seminars.

\section{Evaluation of Main Aspects of Blended Courses}

Figures 2 and 3 demonstrate the study results with regard to the second research question, namely the teachers' attitudes towards the four blended learning general English courses ranging from level $\mathrm{A} 1$ to $\mathrm{B} 2$ and created at the Centre of Foreign Languages at VMU. In that part of the research the teachers were asked to evaluate these blended learning courses in terms of the usefulness and efficiency of their different aspect in the teaching/ learning process. Figure 2 displays the aspects of the four courses which refer to study materials and resources used in the courses. These aspects are regarded by most of the teachers as useful. Meanwhile, Figure 3 shows those aspects which are related to different types of e-communication and which leave the teachers in doubt about their benefits. Given that there are twice as many aspects in the former Figure as in the latter and that there are no aspects where the dominant answer would be negative, it can be concluded that the general attitude of the teachers towards these blended learning course is quite positive.

The teachers are especially positive about the self-check exercises which are presented in an interactive form, the audiovisual materials and the materials aimed at engaging students into the units of the courses. The slide presentations with the explanation of lexical and grammatical patterns, the relevant internet links and the exercises presented in the word and $p d f$ files receive slightly less support but are still evaluate quite positively.

The aspects displayed in Figure 3 include asynchronous eforums, synchronous e-discussions, e-chats as well as econsultations. Although the teachers have reservations about the usefulness of all these aspects, e-consultations receive least of the support and most of doubts. 


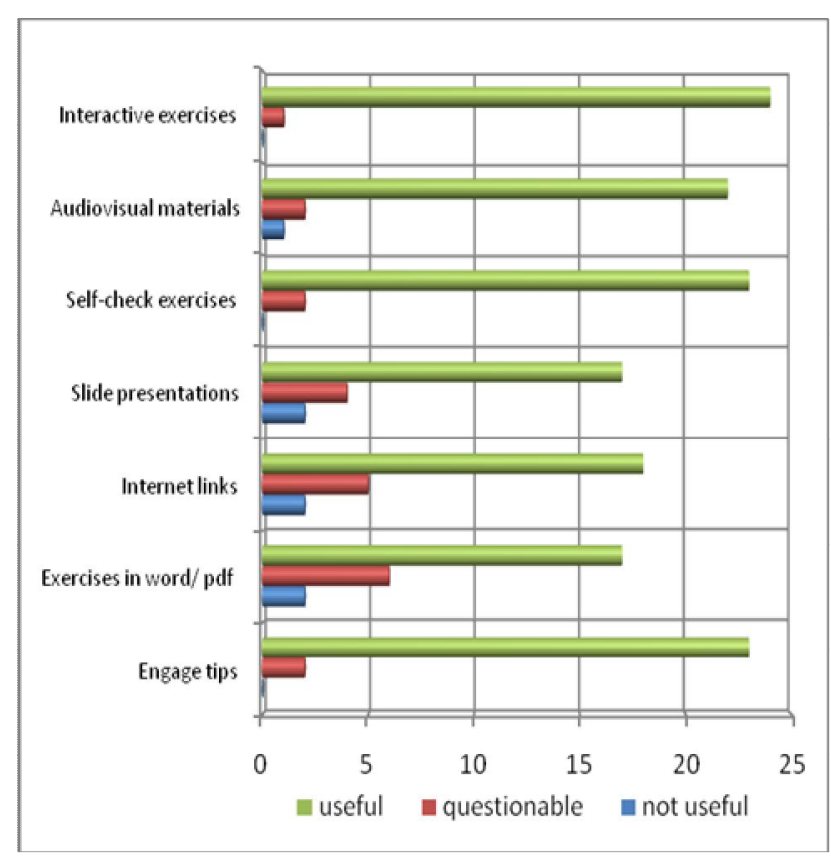

Figure 2. Evaluation of Study Materials.

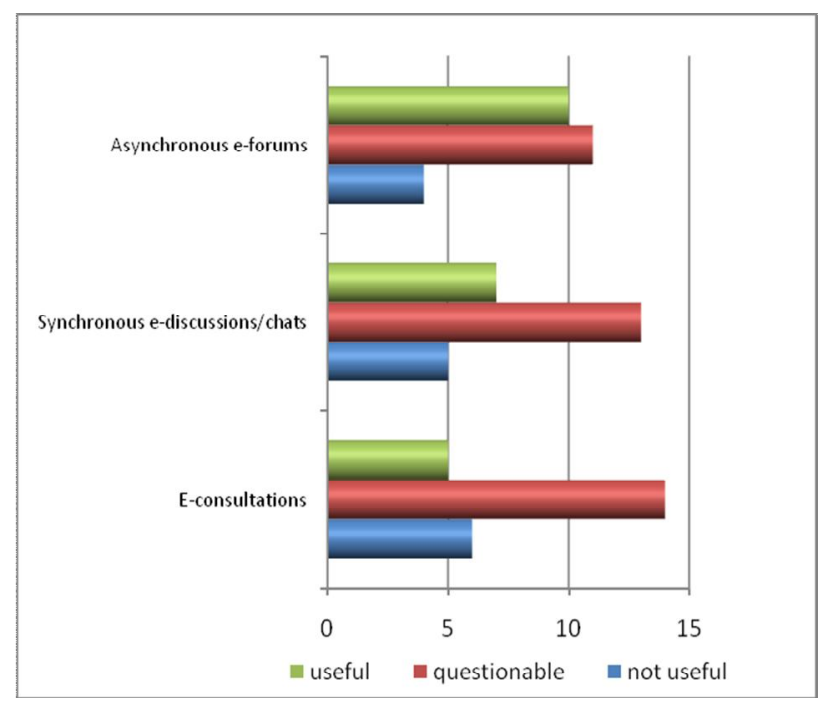

Figure 3. Evaluation of E-communication Types.

On the basis of the results displayed in the two Figures, a conclusion can be drawn that the teachers value those aspects of blended learning which are related to the independence of the students and their autonomous learning. In the meantime, the benefits of those aspects of blended learning which focus on the input of the teacher are regarded as questionable. Two explanations can be suggested for such findings. On the one hand, these findings may show that while acclaiming the factor of independence and autonomy in blended learning, the teachers still prefer the traditional face-to-face interaction for a teacher-learner contact. On the other hand, as suggested by the previously discussed results of the study, the teachers might feel the lack of competence and experience in e- communication and therefore be rather unsure about the usefulness of this form of contact with their students.

The results of the informal interviews with the teachers add more details and clarity to the findings obtained via a questionnaire and presented above. In what follows, the teachers approbatory comment, negative criticism, and suggestions for improvement with regard to the blended learning courses will be discussed.

\section{Approbatory Comments}

The convenience of access is pointed out by the teachers as one of the most significant benefits of distance teaching/ learning in general and the given blended learning courses in particular. In the teachers' view, this feature refers to both processes, i.e. studying and teaching anytime and anywhere. A learner can access the course with all its versatile materials like video recordings, grammar and vocabulary banks at any time and place where he or she has access to a computer and the internet. Likewise, the learners have a convenient access to a teacher's consultation or a discussion of a difficult issue with a colleague in a virtual forum.

Another important advantage, as seen by the teachers, is the learner-centred approach implemented through the application of blended learning. Given that the blended courses follow a continuous thematic outline, all the materials are supplied consistently with grammar theory, active vocabulary lists, interactive self-check exercises which enable the learners to work consistently and independently.

At the same time, the blended learning courses are acclaimed by the teachers for entailing a communicative approach to language learning. The beginner level students (A1) can find the video tasks, with the recordings of Lithuanian speakers talking English, which is quite encouraging for their own communicative production. For the more advanced students, the blended learning courses present an opportunity to drill their communicative skills in forums and chats of the virtual environment of the courses. In the virtual environment, as highlighted by the teachers, communicative competence can be developed in the form of a written production in forums and in the form of an oral production in chats. As generalised by Blake (2008), who presents an overview of empirical research into online language learning, online and blended language learners show better results of written production and communication than their counterparts in traditional classrooms.

\section{Negative Criticism}

There were few points enumerated as negative aspects of the blended learning courses. Almost all of the teachers indicated that the reduced face-to-face element of language learning can be seen as the most negative factor. The teachers point out that this lack of a face-to-face contact can be most problematic for beginner level students or those who need more assistance and guidance in their endeavours. Another aspect indicated by the teachers as negative is the students' lack of motivation to participate in the virtual forums and 
chats. Such comments of the teachers can be seen as reflecting the fact that the application of blended learning does not have a long tradition in language teaching/ learning and teachers might be not very experienced in involving their students in interesting and fruitful activities.

\section{Suggestions for Improvement}

For the teachers, various technical inadequacies make the largest group of the problems which require solutions in order to achieve improvement. Some of the problems are related to the software shortcomings, others to a personal failure or lack of experience in its application. In any case, this comment of the teachers links closely with their expression of a personal wish for the development of their ICT skills. With regard to the content of the blended learning courses, the teachers indeed highlight the need for the continuous development and improvement of the courses. They primarily highlight the necessity to introduce more interactive exercises which, one the one hand, are found especially attractive by the students and, on the other hand, highly assist in autonomous learning.

\section{Conclusions}

The present research shows that the English language teachers display a generally positive attitude towards blended learning. Moreover, the teachers are appreciative with regard to different forms of blending ICT into language classes as for instance classes in the multimedia language teaching laboratory, the introduction of interactive tests and the element of distance learning. Nevertheless, the teachers maintain that the improvement of their personal proficiency in computer skills and the application of ICT is necessary to guarantee the effectiveness and productiveness of blended teaching/ learning. The teachers to a large extent agree about the efficiency of the blended learning courses in terms of the resources contained there, such as video lectures, theory presentations, interactive exercises for self-check and others. However, they express some doubts with regard to the usefulness of the activities in the virtual environment, such as virtual consultations and discussions, which can again be related to their need to improve their overall ICT-awareness. It can also be related to the fact that the young generation of students embrace technological progress more naturally than most of the teachers.

References
1. Bijeikienè, V., Linkevičiūte, E., Pundziuvienè, D., 2009. ICT in Foreign Language Learning and Teaching: Attitudes and Practices. In Language and Culture: New Challenges for the Teachers of Europe//Kalba ir kultūra: nauji iššūkiai Europos mokytojui, Chodzkienè, L. (ed), Vilnius: Vilniaus universiteto leidykla, pp.252-262.

2. Blake, R., 2008. Distance Learning for Second and Foreign Language Teaching. In Second and Foreign Language Education, Encyclopedia of Language and Education, vol. 4, Van Deusen-Scholl, N. and Hornberger, N. H. (eds.), New York: Springer, pp.365-376.

3. Brown, H. D., 2000. Principles of Language Learning and Teaching (4th ed.), White Plains, NY (USA): Addison Wesley Longman.

4. Brown, H. D., 2001. Teaching by Principles: An Interactive Approach to Language Pedagogy (2ed.), White Plains, NY (USA): Addison Wesley Longman.

5. Chapelle, C. A., Jamieson, J., 2008. Tips for Teaching with CALL: Practical Approaches to Computer-assisted Language Learning, New York: Pearson.

6. Common European Framework of Reference for Languages: Learning, Teaching, Assessment, 2001. Council of Europe, Cambridge: Cambridge UP.

7. Daubariene, A., Rinkevičienè, I., Zdanytė, J., 2009. ICT in English Language Teaching - What, Why, and How? In Proceedings of the 3rd international conference on Global Cooperation in Engineering Education: Innovative Technologies, Studies and Professional Development, October 1-3, 2009, Kaunas, Lithuania / Kaunas University of Technology. Kaunas: Technologija, pp.142-145.

8. Davies, G., 2000. CALL (Computer Assisted Language Learning). In Routledge Encyclopedia of Language Teaching and Learning, Byram, M. (ed.), London: Routledge, pp.90-93.

9. Kenning, M., 2008. ICT and Language Learning: From Print to the Mobile Phone. New York: Palgrave Macmillan.

10. Mačianskienè, N., Daukšienė, E., 2008. Impact of the Use of ICT upon University Students' Approach to Learning a Foreign Language. In Proceedings of the 2nd International Multi-Conference on Society, Cybernetics and Informatics, Malpica, F. et al. (eds.), vol. 1, Orlando (USA): the International Institute of Informatics and Systemics, pp.144-149.

11. Makkonen, P., 2008. Is a Seminar Based on Student-created Screen Capture Videos a Meaningful Way of Learning? In Proceedings of the 2nd International Multi-conference on Society, Cybernetics and Informatics. Malpica, F. et al. (eds.), vol. 1, Orlando (USA): the International Institute of Informatics and Systemics, pp.144-149.

12. Malpica, F., Tremante, A., Friedrich, W. (eds.), 2006. Proceedings of Society, Cybernetics and Informatics, vol. 1, Orlando (USA): the International Institute of Informatics and Systemics.

13. Morrow, K. (ed.), 2004. Insights from the Common European Framework, Oxford: Oxford UP.

14. Rutkauskienè, D. et al., 2003. Nuotolinis mokymasis, Kaunas: Technologija

15. Rutkauskienè, D. et al., 2007. Nuotlinio mokymosi dèstytojo vadovas, Kaunas: Technologija.

16. Sharma, P., Barrett, B., 2007. Blended Learning: Using Technology in and Beyond the Language Classroom, Oxford: Macmillan.

17. Shelly, M., 2000. Distance Learning. In Routledge Encyclopedia of Language Teaching and Learning, Byram, M. (ed.), London: Routledge, pp.183-185.

Vilma Bijeikienè, Svetlana Rašinskienè, Lina Zutkienè

Dèstytojų požiūris į mišraus mokymo taikymą bendrosios anglų kalbos paskaitose

Santrauka

Straipsnyje analizuojamos informacinių technologijų panaudojimo bei nuotolinio ir mišraus mokymo(-si) problemos mokant(-is) bendrosios anglu kalbos A1B2 lygmenimis aukštajame moksle. Aprašomas tyrimas pristato dèstytojų požiūị ir patirtį, mokant užsienio kalbos šiuolaikiniais IKT grịstais metodais. Šiandieninė visuomenė ypač jautri ir imli informacinių technologijų naujovėms, jų taikymui bei efektyviam panaudojimui. Kompiuterinè kalba šiuolaikiniams studentams yra tapusi „,gimtaja kalba“, kurią jie išmoksta ankstyvoje vaikystejje kompiuterinių žaidimų forma ir kuri natūraliai įsilieja ị visas jaunimo veiklas tiek privačiame gyvenime, tiek ir viešosiose erdvėse. Esant tokiai situacijai, užsienio kalbų dèstytojams efektyvus ir produktyvus IKT panaudojimas tampa tikrai nelengva užduotimi, netgi iššūkiu. Straipsnyje pateikiami ir analizuojami teigiami ir neigiami mišraus kalbų mokymo(-si) metodikos aspektai, kai kalbų mokymo(-si) procesas vyksta derinant virtualų ir auditorinị darbą. Šiuo tyrimu autorès siekia palengvinti minètą dėstytojų užduotị, išsiaiškinant ir 
išanalizuojant dėstytojams kylančias abejones, jų poreikius bei pastabas. Tyrimas atliktas Vytauto Didžiojo universiteto Užsienio kalbų centre, respondentai 24 anglų kalbos dėstytojai. Tyrimas paremtas kokybinio tyrimo metodologija, naudojant neformalaus interviu bei anketavimo metodą.

Straipsnis ịteiktas 201008

Parengtas spaudai 201101

\section{The Authors}

Vilma Bijeikiene, Dr., associate professor at the Centre of Foreign Languages, Vytautas Magnus University, teaching general English courses and ESP courses of English for Politics and Legal English. She defended her doctoral dissertation on gender and political discourse analysis at Bergen University, Norway. She has presented papers and published in Lithuania and internationally.

Address: Vytautas Magnus University, Centre of Foreign Languages, K. Donelaičio str. 52-603, 44244 Kaunas, Lithuania.

E-mail: v.bijeikiene@ukc.vdu.lt

Svetlana Rašinskiene, lecturer at the Centre of Foreign Languages, Vytautas Magnus University, teaching general English courses and an ESP course of Environmental English. She is a co-author of several books for teaching and learning English, as well as publications in reviewed journals.

Address: Vytautas Magnus University, Centre of Foreign Languages, K. Donelaičio str. 52-603, 44244 Kaunas, Lithuania.

E-mail: s.rasinskiene@ukc.vdu.lt

Lina Danute Zutkiené, EFL teacher at the Center of Foreign Languages, Vytautas Magnus University, for more than seventeen years. She is a co-author of several books for teaching and learning English, as well as publications in reviewed journals. She also has a master degree in business administration. Address: Vytautas Magnus University, Centre of Foreign Languages, K. Donelaičio str. 52-603, 44244 Kaunas, Lithuania.

E-mail:1.zutkiene@ukc.vdu.lt 